\title{
Gore and Bush back rise in science spending
}

\section{Colin Macilwain, Washington}

Both of the main candidates in this year's tightly contested US presidential election are promising to boost research funding especially at the National Institutes of Health $(\mathrm{NIH})$ - and maintain the existing structure of research agencies, according to statements from their campaign staff.

The similar approaches to science and technology policy taken by vice-president Al Gore, the Democrat nominee, and George W. Bush, the Republican, contrast with some previous campaigns. In 1992, for example, Democrat challenger Bill Clinton pledged to revive US industry with billions of dollars worth of new technology programmes.

This time, the Bush campaign is pledging an extra $\$ 20$ billion over five years for military research and development. But it is not clear how much of this would be spent on science, or even on applied science: four-fifths of current military R\&D spending goes on weapons development and testing.

The similar approaches were clear at a debate last week between representatives of the Gore and Bush camps, organized by the Washington Science Policy Alliance.

But the debate did reveal sharp differences on areas of policy influenced by scientific knowledge, such as global warming and ballistic missile defence. Bush promises to deploy national missile defence, whereas Gore says he will consider its effectiveness and the views of US allies before deployment. Gore will seek Senate ratification for the Kyoto Protocol on climate change; Bush wants to renegotiate it.

In addition, Bush promises to fight to ensure that US farmers' genetically modified crops are allowed to enter the European Union. David Beier, Gore's chief domestic policy advisor and a former executive with biotechnology firm Genentech, says that "we need to be very careful" about dealing with agricultural biotechnology.

Both candidates are committed to doubling the NIH's budget from its 1998 level of $\$ 13.5$ billion to $\$ 27$ billion by 2003 or soon after. Both have also pledged more money for the National Science Foundation, with Gore saying that he hopes to double its budget in five years.

Former Republican congressman Bob Walker, speaking for the Bush campaign at the debate, said that cuts in military research under the Clinton administration "had crippled a lot of our universities". But Beier argued that the vice-president's interest in science and technology was "probably greater than that of any presidential candidate in history".

Neither candidate has drawn up detailed proposals for science and technology,

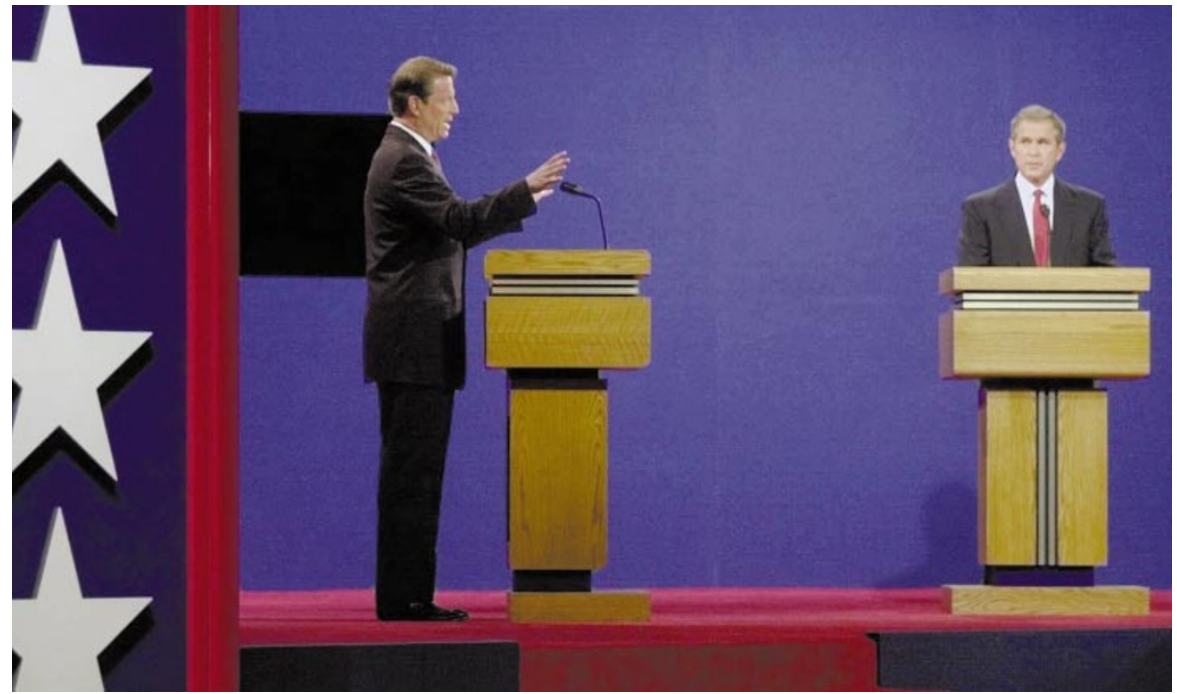

Similar approach: Bush (right) and Gore both promise to boost science funding if elected.

although both campaigns summarized their plans in questionnaires published in Physics Today this month and Science this week.

Hopes that Bush would devote a speech to science and technology are receding, although Gore may do so shortly, possibly on a visit to Michigan.

Science lobbyists, disappointed at the lack of science and technology in the campaigns, note that the tightness of the race - and the candidates' need to focus relentlessly on hotbutton issues such as healthcare for the elderly-has diverted them from speeches or policy papers on less mainstream topics.

Also, Gore is expected to win easily in science-rich states such as California, Massa-

chusetts and Maryland. Of large states where the election could go either way, only Michigan has a major stake in research and development.

The candidates have "much greater differences on other stuff" than on research policy, says Al Teich, head of science and technology policy at the American Association for the Advancement of Science, who helped to organize the debate.

In the Science questionnaire, Gore says: "My favourite subject at school was science." Apparently impressed, Nobel laureates Murray Gell-Mann and Harold Varmus are circulating a letter urging scientists and engineers to support the Gore campaign.

\section{Project offers free mouse sequence}

Paul Smaglik, Philadelphia

\section{\& Alison Abbott, Munich}

Researchers will get a free version of the mouse genome about two years earlier than planned, thanks to a public-private collaboration announced last week. A consortium will pump \$58 million into the project - enough to sequence the organism three times over by April.

Celera Genomics, of Rockville, Maryland, will finish its mouse project next month, but the information will be available only to subscribers. In supporting the public project, rather than paying to use Celera's databases, the consortium's biggest pharmaceutical sponsors, Merck and SmithKline Beecham, have committed themselves to making what their spokespersons call "precompetitive

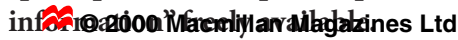

The companies have each given $\$ 6.5$ million to the public effort. Other sponsors include Affymetrix, the US National Institutes of Health and Britain's Wellcome Trust.

In announcing the consortium last week at a meeting of the American Society of Human Genetics, Francis Collins, director of the National Human Genome Research Institute, emphasized that the project is not competing with Celera, in contrast to the portrayal of their sequencing efforts of the human genome. “This is not a race," he said.

The mouse sequence will make it easier to understand the human genome, as the two share many genes - although not the repetitive stretches of 'junk' DNA that make up a significant part of each.

The two mouse projects use different strategies. Celera is sequencing three different strains of mouse once each, whereas the public effort is sequencing the common 'black six' strain three times. 


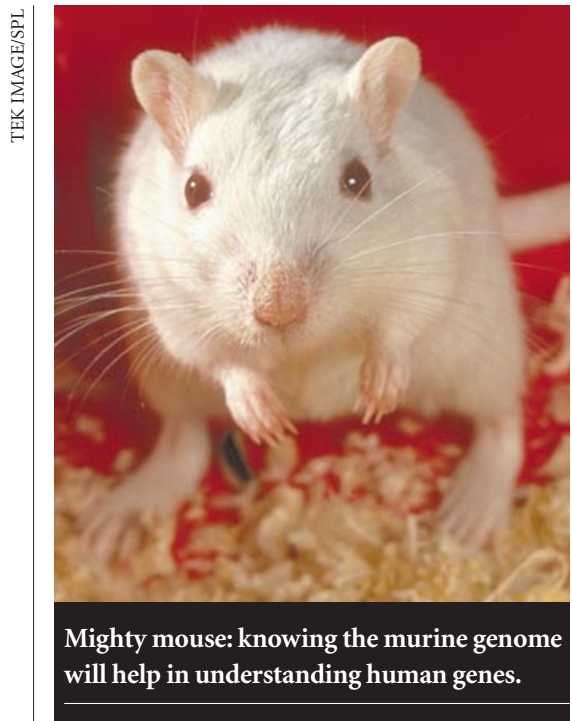

- Celera's effort will allow subscribers to detect subtle differences between strains; the public project will give a more complete view of one strain.

But Celera president Craig Venter sees duplication, not difference. The consortium's effort is a "waste of public money", he says. "It would make more sense for scientists to pay for Celera licences than to pay for the genome to be sequenced again."

Roger Schultz, assistant professor of human growth and development at the University of Texas Southwestern Medical Center, sees merit in the public approach, which aims to sequence both mouse and human genomes several times more than Celera intends.

"Personally, I'm more interested in the high-quality human product, although a good mouse project can help you find highly conserved regions, and therefore genes," he says. The Texas centre is one Celera's several academic subscribers.

Celera subscribers will get the first view of the mouse, as the company expects to finish sequencing next month. If the public project finishes its first phase in March, as planned, the data could be largely assembled by the end of next year. Plans announced by the Human Genome Project last autumn called for a draft of the mouse by the end of 2003, to be fully completed by the end of 2005 .

The Whitehead Institute at the Massachusetts Institute of Technology, Washington University in St Louis, and the British Sanger Centre near Cambridge will do the bulk of the public project's shotgun sequencing. Washington University is halfway through building a map of the mouse that will help in assembling a rough draft from the mouse shotgun data. http://www.nhgri.nih.gov/NEWS/MouseGenes/ mouse_release.html

\section{Anger as Spain boosts R\&D figures with defence money}

\section{Xavier Bosch, Barcelona}

Spanish scientists are expressing anger that the government is exaggerating its generosity towards research by including a number of military projects in the national research and development (R\&D) budget.

Late last month, the Spanish government announced an $11.3 \%$ increase in next year's state spending on $\mathrm{R} \& \mathrm{D}$, following agreement by the cabinet to boost $\mathrm{R} \& \mathrm{D}$ spending by Ptas 572 billion (US $\$ 3$ billion).

According to a report accompanying the budget figures, basic and applied research managed by the Higher Council of Scientific Research (CSIC) and the Ministry of Health will receive a $7.6 \%$ increase to Ptas 112 billion. But a significantly larger increase of $12.6 \%$ will go to the general categories of 'technological R\&D' and 'information society R\&D'.

The government report says this spending is intended to boost "competitive technological research as well as to finance the development of the information society". But Ramón Marimon, secretary of state for scientific policy at the Ministry of Science and Technology (MST), admits that the budget for 'technological R\&D' - the largest item in the whole R\&D budget at about Ptas 300 billions - is devoted to technological projects for military use.

According to information on the website of the former Ministry of Industry and Energy, which has been replaced by the MST, the minister has allocated Ptas 500 billion since 1997 to the Ministry of Defence for the construction of tanks, frigates and fighter planes. These funds have been officially listed as ' $R \& D$ ' funds, and their military nature has not been explicitly stated.

This military spending may explain the impressive growth of the nation's R\&D budget from Ptas 207 billion in 1995 to 507 billion in 2000, which, according to the budget report, supposes "a cumulative annual mean rate [of R\&D investment] of 19.6\%".

"Not only is the government trying to disguise the true situation, but a significant

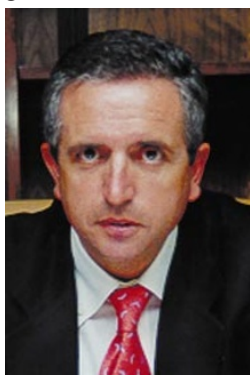
amount of the $R \& D$ budget is spent on military research, while the money set aside for [civilian] research remains scarce," says Óscar Fornas, a senior biomedical researcher at the University of Barcelona.

The MST has Marimon: admits to military spending. the proportion of gross

\section{LATEST SPANISH MILITARY CAMOUFLAGE UNVEILED!}

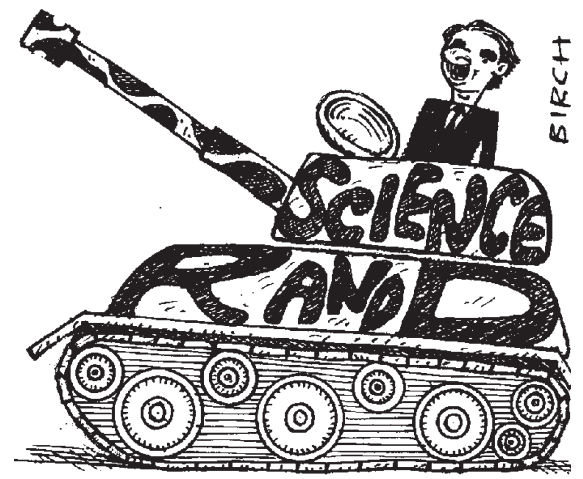

national product spent on research from $0.9 \%$ to $2 \%$ by 2003 , in line with other advanced countries.

But if this figure is reached by devoting a disproportionate amount of funds to military research, then "something is very wrong", says Jordi Camí, professor of pharmacology at the University Pompeu Fabra in Barcelona.

Mariano Esteban Rodriguez, director of the National Centre of Biotechnology in Madrid, says scientists "must know how much money there really is for research", and adds that "transparency is essential to know how much money we can spend".

Luis Rull, professor of physics at the University of Seville, says the situation was the same last year, when it was criticized by the Spanish Association for the Advancement of Science and Technology.

Spaniard Juan Manfredi, professor of mathematics at the University of Pittsburgh, says the way the Spanish budget is presented is significantly different from the situation in the United States, where a clear distinction is made between civilian and military spendings on research.

He adds that a line in the Spanish budget described as military R\&D ('research and studies of armed forces') should not be included in the research budget, as most of the money "represents the adaptation and fitting of existing technologies".

While admitting the substantial spending on military projects, Marimon points out that at least 2,000 new research posts will be created in the public sector.

He has also announced that companies involved in $\mathrm{R} \& \mathrm{D}$ will no longer pay value added tax (VAT) on their activities. But he admits that it would be "reasonable" to increase the amount of transparency in the Spanish budget in the future, and promises to try to achieve this. 